\title{
The Growth of Oil Palm Seedlings using a Combination Medium of Organic Oil Palm Empty Fruit Bunch and NPK Fertilizer at Main Nursery
}

\author{
Hapsoh, Isna Rahma Dini*, Wawan and Astri Helga Sianipar \\ Department of Agrotechnology, Agriculture Faculty, Universitas Riau \\ Kampus Bina Widya KM 12,5 Simpang Baru Panam, Pekanbaru, Indonesia, \\ e-mail: isnarahmadini19@gmail.com
}

Received July 15, 2019; Revised April 28, 2020; Accepted 4 May 2020

\begin{abstract}
Oil palm (Elaeis guineensis Jacq.) holds a very strategic role in the Indonesia economy. Plants that have reached the economical age of 25 years need to be replanted using qualified oil palm seedling. The qualified seedling is obtained through proper fertilization. The combination of NPK fertilizer and organic material of oil palm empty fruit bunches (OPEFB) which has been given a cellulolytic bacterial consortium can provide sufficient nutrients for the growth of oil palm seedlings. The study aimed to determine the effect of giving a combination of OPEFB organic material, cellulolytic bacterial consortium, and NPK fertilizer on the growth of oil palm seedling (Elaeis guineensis Jacq.) at main nursery. This experiment used a single factor experiment arranged in a Completely Randomized Design (CRD). The treatments were a $100 \%$ NPK, a OPEFB compost, a $50 \%$ NPK + OPEFB compost, a $50 \%$ NPK + OPEFB + Cellulolytic bacterial consortium, and a OPEFB + cellulolytic bacterial consortium. The results showed that the application of inorganic fertilizers combined with organic fertilizers (a OPEFB compost and a OPEFB + cellulolytic bacterial consortium) had a good effect on each parameter. Giving organic fertilizer without inorganic fertilizer had not affected plant growth on all parameters. Application of a OPEFB compost and a OPEFB + cellulolytic bacterial consortium can reduce the use of inorganic fertilizers by $50 \%$.
\end{abstract}

Keywords: NPK, Oil palm, OPEFB compost

\begin{abstract}
ABSTRAK
Kelapa sawit (Elaeis guineensis Jacq.) memegang peranan yang sangat strategis dalam perekonomian Indonesia). Tanaman yang telah mencapai umur ekonomis yaitu 25 tahun perlu dilakukan peremajaan (replanting) dengan menggunakan bibit kelapa sawit yang berkualitas. Bibit yang berkualitas diperoleh melalui pemupukan yang tepat. Kombinasi pupuk NPK dan bahan organik TKKS yang telah diberi konsorsium mikrob selulolitik dapat memberikan unsur hara yang cukup untuk pertumbuhan bibit kelapa sawit. Tujuan penelitian untuk mengetahui pengaruh pemberian kombinasi bahan organik TKKS, konsorsium mikrob selulolitik dan pupuk NPK terhadap pertumbuhan bibit kelapa sawit di pembibitan utama. Penelitian ini menggunakan Rancangan Acak Lengkap (RAL) dengan 5 perlakuan. Perlakuan pertama $100 \%$ NPK, perlakuan ke dua kompos TKKS, perlakuan ke tiga $50 \%$ NPK + kompos TKKS, perlakuan ke empat 50\% NPK + TKKS + konsorsium mikrob, perlakuan ke lima TKKS + konsorsium mikrob selulolitik. Hasil penelitian menunjukkan bahwa pemberian pupuk anorganik yang dikombinasikan dengan pupuk organik (kompos TKKS maupun TKKS + konsorsium mikrob selulolitik) memberikan pengaruh yang baik pada setiap parameter. Pemberian pupuk organik tanpa pupuk anorganik tidak dapat memberikan pertumbuhan tanaman pada semua parameter. Aplikasi kompos TKKS maupun TKKS + konsorsium mikrob selulolitik mampu mengurangi penggunaan pupuk anorganik hingga $50 \%$.
\end{abstract}

Kata Kunci: Kelapa sawit, kompos TKKS, NPK 


\section{INTRODUCTION}

Palm oil (Elaeis guineensis Jacq.) play a very strategic role in the Indonesian economy, namely as a producer of edible oil, industry, and biofuels (biodiesel). Palm oil production in Indonesia comes from palm fruit grown in several regions in Indonesia, one of which is Riau Province. Statistics of Riau Province (2018) showed that in 2017 the area of oil palm plantations reached $2,776,500 \mathrm{ha}$, of the total land area that most of them have undergone a phase of less yield because plants have reached the economic age of 25 years. Therefore, oil palm plants need to be replanting.

According to the Plantation Fund Management Agency (2018), the government will begin replanting smallholder oil palm plantations covering 25,423 hectares for Riau Province in 2018. The replanting activities require quality oil palm seeds to be used instead of plants that are no longer productive. Quality is the main factor affecting plant productivity. This is in line with that stated by Pahan (2010) that the actual investment for commercial plantations is in the plant material to be planted in the form of seeds because it is a source of profit for the company. Jannah et al. (2012) added that nurseries are the first step in preparing good quality seedling because it will determine the productivity and longevity of plant production. Things that must be considered in the process of oil palm nurseries are fertilization.

According to Kiswondo (2011), fertilization as a part of agricultural intensification is an effort aimed at increasing the supply of plant nutrients to increase production and quality of crop yields. One effort to provide nutrients for oil palm plants can be done by adding organic matter directly to the planting media. Organic materials that can be used to oil plantation are oil palm empty fruit bunches (OPEFB) (Sari et al. 2015; Sembiring et al. 2015; Yi et al. 2019), and palm fronds (Ariyanti et al. 2017; Ariyanti et al. 2019). Based on Al-Khoiri (2013) research, giving OPEFB to haplik podsolic soil type, plintik podsolic, district kambisol and district gleysol under oil palm stands can improve soil physical properties i.e. decrease bulk density and particle density, and increase total pore space, permeability, infiltration rate and water content at a depth of $0 \mathrm{~cm}-20 \mathrm{~cm}$. Also, the addition of $1 \mathrm{~kg}$ of oil palm empty fruit bunches and/or $1 \mathrm{~kg}$ of crude palm oil ash per seedling in a recommended $1 / 2$ dose treatment results in optimum growth of oil palm seedlings and can replace the use of inorganic fertilizer $1 / 2$ dose recommendation (Jesus 2012).
The addition of organic matter from the OPEFB is also expected to maintain soil moisture because it functions as a mulch. Based on the results of the Situmorang et al. (2015), the giving of OPEFB organic mulch increased the total pore space, water content, $\mathrm{pH}$, organic $\mathrm{C}$, total $\mathrm{N}$, and $\mathrm{K}$ which were significantly different in oil palm plantations. The spread of the OPEFB mulch was also able to suppress weed growth.

Provision of nutrients through the addition of OPEFB organic matter directly if there are microorganisms that decompose the organic matter into compost OPEFB. Microorganisms that can accelerate the process of decomposition of OPEFB one of them is cellulolytic bacterial. Saraswati et al. (2010) stated that cellulase enzymes produced by cellulolytic bacterial were able to accelerate the decomposition process of organic matter containing cellulose. Therefore, cellulolytic bacterial can decompose the cellulose contained in the OPEFB. This can support a sustainable system for managing oil palm plantations through the use of biofertilizers (Bakeri et al. 2019).

Based on the research of Hapsoh et al. (2016), they obtained six potential cellulolytic bacterial isolates consisting of two bacterial isolates from rice straw (Bacillus cereus JP6 and Bacillus cereus JP7), two bacterial isolates from oil palm empty fruit bunches (Proteus mirabilis OPEFB3 and Proteus mirabilis OPEFB7), and two isolates the origin of acacia litter (Providencia vermicola SA1 and Bacillus cereus SA6). The six cellulolytic bacterial isolates from several different sources are expected to work synergistically so that it has the potential to accelerate the composting process.

Palm oil seeds require a lot of nutrients such as nitrogen $(\mathrm{N})$, phosphorus $(\mathrm{P})$, and potassium $(\mathrm{K})$ which are not enough just to give organic fertilizer but need to be combined with inorganic fertilizers. According to Sari et al. (2015), the combination of NPK fertilizer and organic fertilizer from empty bunches was able to increase seedling height, the number of oil palm seedlings, and stem diameter. One of the inorganic fertilizers that has a good influence on plant growth is NPK fertilizer (16:16:16). The results of other studies conducted by Adnan et al. (2015), showed that the addition of NPK fertilizer (16:16:16) can increase plant height, stem diameter and dry weight of oil palm plants at the age of 3 months. Sijabat and Wawan (2017)

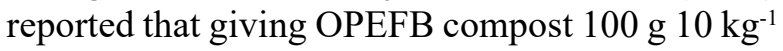

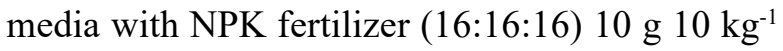
media was a combination of treatments that resulted in the highest growth of 6 months old palm oil seedlings in ultisol soil media. 
Based on the above explanation, the study aimed to determine the effect of giving a combination of OPEFB organic material, cellulolytic bacterial consortium, and NPK fertilizer against the growth of oil palm seedling (Elaeis guineensis Jacq.) at main nursery.

\section{MATERIALS AND METHODS}

\section{Study Site}

This experiment was conducted at the University of Riau Experimental Field, 12.5 KM Bina Widya Campus Simpang Baru, Tampan District, Pekanbaru.

\section{Preparation of Oil Palm Seeds to be Used in the Field Experiments}

The oil palm seedling used came from a 3month-old Dura $\mathrm{x}$ Pisifera crossing originating from Medan Marihat PPKS. The seedling used has good growth and are free from pests and diseases. The oil palm seedlings are selected whose growth is the same as the plant height of $\pm 25 \mathrm{~cm}$. The planting medium used for oil palm nursery is topsoil, Inceptisol soil. The soil comes from the University of Riau's Faculty of Agriculture experimental garden with a depth of up to $20 \mathrm{~cm}$. The soil taken is then dried, then the soil is sieved using a 25 mesh sized sieve. The soil is weighed $10 \mathrm{~kg}$ each and then put in a polybag measuring $30 \mathrm{~cm} \times 35 \mathrm{~cm}$.

\section{Composting Processes}

The cellulolytic microbes prepared as treatment were two bacterial isolates from oil palm empty fruit bunches Proteus mirabilis OPEFB3 and Proteus mirabilis OPEFB7, two isolates of Bacillus cereus JP6 genus and Bacillus cereus JP7, and two acacia litter isolates genus Providencia vermicola SA1 and Bacillus cereus SA6 (Hapsoh et al. 2016). OPEFB compost starts with making cellulolytic bacterial decomposer starter was carried out by growing the six cellulolytic bacterial isolates on OPEFB media $\left(0.02 \% \mathrm{MgSO}_{4} .7 \mathrm{H}_{2} \mathrm{O} ; 0.03 \% \mathrm{NH}_{4} \mathrm{NO}_{3} ; 0.05 \%\right.$ $\mathrm{K}_{2} \mathrm{HPO}_{4} ; 0.1 \% \mathrm{KH}_{2} \mathrm{PO}_{4} ; 0.002 \% \mathrm{FeSO}_{4} .7 \mathrm{H}_{2} \mathrm{O}$; $0,004 \% \mathrm{CaCl}_{2} .2 \mathrm{H}_{2} \mathrm{O} ; 0.2 \%$ yeast extract, $1 \%$ OPEFB).

The six cellulolytic bacterial isolates were grown in $10 \mathrm{ml}$ Nutrient Broth (1\% of OPEFB media) and incubated for one day at room temperature $20-25^{\circ} \mathrm{C}$. After that, the inoculant was grown in $100 \mathrm{ml}$ OPEFB media and incubated for
3 days at the same temperature. As many as 20 $\mathrm{ml}$ of the bacterial suspension was transferred into the beaker glass, then added $20 \mathrm{~g}$ of granulated sugar and $980 \mathrm{ml}$ of rice washing water so that the solution volume reached $1 \mathrm{~L}$. Then the decomposer starter was left for 3 hours (Kurniawan et al. 2014a). Composting was done 1 month before the research begins. In composting, a ratio of decomposer starter with OPEFB was 1:2 (1 L stater: $2 \mathrm{~kg}$ OPEFB), while the indirect application (OPEFB + cellulolytic bacterial consortium treatment), the ratio of decomposer starter with OPEFB was 1:1 $(100 \mathrm{ml}: 100 \mathrm{~g}$ OPEFB).

\section{Method of Fertilizer Treatment}

The treatment method in this research consisted of 3 methods application, namely inorganic fertilizer, compost, and OPEFB + cellulolytic bacterial application. Application NPK fertilizer is carried out using NPK compound fertilizer (16:16:16). NPK fertilizer was given based on the dose level, namely $50 \%$ NPK as much as $10 \mathrm{~g} \mathrm{polybag}^{-1}$ and $100 \%$ NPK as much as $20 \mathrm{~g} \mathrm{polybag}^{-1}$. This activity was carried out in two stages which were one week before planting and one month after planting. In the application compost and OPEFB + cellulolytic bacterial, the amount of compost and raw OPEFB gave $100 \mathrm{~g}$ polybag $^{-1}$ each.

\section{Data Analysis}

The experiment was design in a Completely Random Design (CRD) with a single factor experiment to test the 5 treatments, namely $\mathrm{M}_{1}$ : $100 \% \mathrm{NPK}, \mathrm{M}_{2}$ : OPEFB compost, $\mathrm{M}_{3}: 50 \% \mathrm{NPK}$ + OPEFB compost, $\mathrm{M}_{4}: 50 \% \mathrm{NPK}+$ OPEFB + cellulolytic bacterial consortium, and $\mathrm{M}_{5}$ : OPEFB + cellulolytic bacterial consortium. The data obtained were tested by simple statistics and continued with the Duncan Multiple Range Test (DMRT) with a $5 \%$ test. The observations in this research consisted of plant height, number of leaves, total leaf area, stem diameter, root to shoot ratio, and plant dry weight.

\section{RESULTS AND DISCUSSION}

\section{Increase in Plant Height of Oil Palm Seedling}

The results of the analysis of variance showed that NPK fertilizer and TKKS compost significantly affected plant height after two months and three 
Table 1. Plant height $(\mathrm{cm})$ of oil palm seedling in each treatment tested during three months of planting.

\begin{tabular}{lcrr}
\hline \multicolumn{1}{c}{ Treatment } & $\begin{array}{c}1 \text { month after } \\
\text { planting }\end{array}$ & $\begin{array}{c}2 \text { months after } \\
\text { planting }\end{array}$ & $\begin{array}{c}3 \text { months after } \\
\text { planting }\end{array}$ \\
\hline $\mathrm{M}_{1}: 100 \%$ NPK & $3.497 \mathrm{a}$ & $10.830 \mathrm{a}$ & $17.162 \mathrm{a}$ \\
$\mathrm{M}_{2}:$ OPEFB compost & $1.080 \mathrm{a}$ & $4.077 \mathrm{~b}$ & $8.910 \mathrm{~b}$ \\
$\mathrm{M}_{3}: 50 \%$ NPK + OPEFB compost & $3.500 \mathrm{a}$ & $10.497 \mathrm{a}$ & $17.662 \mathrm{a}$ \\
$\mathrm{M}_{4}: 50 \%$ NPK + OPEFB + cellulolytic bacterial consortium & $2.790 \mathrm{a}$ & $8.580 \mathrm{a}$ & $17.330 \mathrm{a}$ \\
$\mathrm{M}_{5}:$ OPEFB + Cellulolytic bacterial consortium & $0.580 \mathrm{a}$ & $3.412 \mathrm{~b}$ & $9.745 \mathrm{~b}$ \\
\hline
\end{tabular}

Note: The numbers in the column are followed by different lowercase letters significant effect according to the DMRT advanced test at the level of $5 \%$.

months after planting. The average increase in plant height after a DMRT further test at $5 \%$ is presented in Table 1.

Table 1 shows that the increase in plant height after 1 month of planting was not significantly different in all treatments. This was likely due to the nutrients supplied through each treatment have not shown a significant effect on plants. After 2 months of planting, $M_{1}$ treatment produced the highest plant height which was significantly different from the $M_{2}$ and $M_{5}$ but not significantly different from other treatments. It is suspected NPK fertilizer can provide nutrients quickly for plant growth. According to Ariyanti (2019), the availability of nitrogen nutrients in the soil can stimulate vegetative growth, namely an increase of stems and leaves and plant height. Kaya (2014) stated that inorganic fertilizer can provide nutrients quickly for plant growth and increase soil chemical fertility because inorganic fertilizers are hygroscopic, which can absorb or bind water molecules from free air so that they are easy to melt and can easily be absorbed by plant roots.

After 3 months of planting, the highest increase in plant height was produced by $\mathrm{M}_{3}$ treatment. The treatment was significantly different from the $M_{2}$ and $\mathrm{M}_{5}$ treatments but not significantly different from other treatments. This was likely due to the application of OPEFB compost fertilizer was slowly providing nutrients for plant growth. Sundram et al. (2019) said that nutrient content of organic fertilizers is for the most invariably low compared to inorganic fertilizers. Based on the results of the analysis that has been carried out nutrient content in OPEFB was $\mathrm{N} 1.52 \%, \mathrm{P} 0.30 \%$, and $\mathrm{K} 4.52 \%$. The content of organic matter is thought to be insufficient for palm oil seedling, so it must be combined with inorganic fertilizer. This is in line with the research of Hasibuan et al. (2014) which stated that the provision of OPEFB compost without the addition of NPK tended to show a lower increase in plant height when compared with the combination of OPEFB and NPK addition. Ariyanti et al. (2017) reported that the height of sugar palm plants not yet produced also experienced an increase due to the administration of $25-50 \%$ of organic fertilizer combined with 50 $75 \%$ inorganic fertilizer.

Compost can also improve the structure of the planting medium to be better. According to Yan and Gong (2010), using organic fertilizer can improve soil organic content. Yeboah et al. (2009) stated that the combination of inorganic fertilizers with organic fertilizers generally increases growth because organic matter can improve soil conditions so that nutrients become more available to plants. Rosenani et al. (2016) added the addition of organic fertilizers (oil palm waste compost) to soil increased oil palm seedling growth up to $70 \%$ at prenursery. However, the use of only compost is not enough to meet the nutritional needs of plants, so it must be combined with inorganic fertilizers to produce better plant height growth. Yi et al. (2019) added that the application of inorganic fertilizers does not much improve the physicochemical properties of the soil when compared to the combination of both. This was what causes that the $M_{3}$ and $M_{4}$ treatments gave the effect of increasing the height of oil palm seeds better than $M_{1} M_{2}$ and $M_{5}$ treatments. This is also supported by Sijabat and Wawan (2017), where the

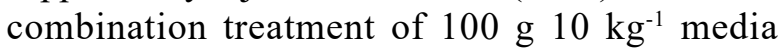

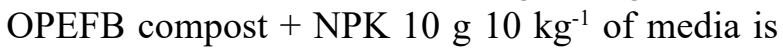
the best compared to all treatments and produces the highest average plant height of $37.70 \mathrm{~cm}$ at age 3 month.

\section{Increase in Number of Leaves (strands) of Oil Palm Seedling}

Based on the results of the analysis of variance, the addition of some NPK, OPEFB and OPEFB compost treatments significantly affected the increase in the number of leaves. The average increase in the number of leaves after further DMRT testing at $5 \%$ is presented in Table 2 . 
Table 2. Increasing the number of leaves of oil palm seedlings (strands) in each treatment tested.

\begin{tabular}{lccc}
\hline Treatment & $\begin{array}{c}\text { Number of } \\
\text { leaves opened } \\
\text { perfectly at the } \\
\text { beginning }\end{array}$ & $\begin{array}{c}\text { Number of } \\
\text { leaves opened } \\
\text { perfectly at the } \\
\text { end }\end{array}$ & $\begin{array}{c}\text { Increase in the } \\
\text { number of } \\
\text { leaves opens } \\
\text { perfectly }\end{array}$ \\
\hline $\mathrm{M}_{1}: 100 \% \mathrm{NPK}$ & 6.3 & 10.475 & $4.165 \mathrm{ab}$ \\
$\mathrm{M}_{2}:$ OPEFB compost & 5.7 & 8.4 & $2.662 \mathrm{~d}$ \\
$\mathrm{M}_{3}: 50 \% \mathrm{NPK}+$ OPEFB compost & 6.37 & 11.22 & $4.827 \mathrm{a}$ \\
$\mathrm{M}_{4}: 50 \% \mathrm{NPK}+$ OPEFB + cellulolytic bacterial consortium & 6.22 & 10.22 & $3.915 \mathrm{bc}$ \\
$\mathrm{M}_{5}:$ OPEFB + cellulolytic bacterial consortium & 6.05 & 9.22 & $3.162 \mathrm{~cd}$ \\
\hline
\end{tabular}

Note: The numbers in the column are followed by different lowercase letters significant effect according to the DMRT advanced test at the level of $5 \%$.

Table 2 shows that the $M_{3}$ treatment was the highest of the number of leaves, however it was not significantly different from the $M_{1}$ treatment, but significantly different from other treatments. It was suspected that if only NPK fertilizer is given, it will dissolve quickly so that NPK fertilizer will slowly contribute fewer nutrients to plants. According to Sutedjo (2008) that inorganic fertilizers dissolve easily in water because they are hygroscopic so that inorganic fertilizer application to the soil can increase the availability of nutrients quickly for plants. If the plant is only given NPK fertilizer, it will slowly reduce the quality of the soil and will invite negative effects on the soil includes changes in the physical, chemical, and biological properties within the soil (Sundram 2019). That is why the highest amount of open leaves was found in $\mathrm{M}_{3}$ treatment compared with $M_{1}$ treatment. This is supported by Astralyna (2009) which states that the use of compost is very supportive of improving soil quality both physically, biologically, and chemically so that nutrients can be available. Anwar (2009) added that organic fertilizer such as OPEFB compost has the effect of increasing soil pore space for the better and providing nutrient intake in soil fauna so that nutrients are available for plant growth. Organic matter content in the soil can increase the effectiveness of inorganic fertilization because it can bind nutrients and increase the amount of negative charge so that the soil cation exchange capacity is high (Herviyanti et al. 2012).

The combination of compost and inorganic fertilizer will provide sufficient macro and micronutrients in the formation of leaves. Nutrients needed for leaf formation are elements $\mathrm{N}$ and $\mathrm{P}$. Lakitan (2007) stated that plants that do not get additional Nitrogen will grow stunted and the leaves that are formed are also smaller, thinner, and the numbers will be smaller, while plants that get additional nitrogen nutrients will form more leaves and width. Nutrient $\mathrm{N}$ in OPEFB compost generally ranged from $1.34-2.03 \%$. In the analysis of the OPEFB compost fertilizer, nitrogen content reached $1.52 \%$. Nengsih (2015) added that the treatment of soil planting media + OPEFB compost (1:2) had a significantly different effect from the treatment of soil + OPEFB compost (1:1) on the number of oil palm seedling fronds. Besides, Sembiring et al. (2015) stated that the combination of $50 \mathrm{~g}_{\text {humic }}{ }^{-1}$ acid polybag and $75 \mathrm{~g} \mathrm{polybag}^{-1}$ compost OPEFB gave the highest increase in plant height, number of leaves, stem diameter, root to shoot ratio, and dry weight compared to other treatment combinations.

\section{Total Leaf Area $\left(\mathrm{cm}^{2}\right)$ of Oil Palm Seedlings}

The results of the analysis of variance on the observation of the total leaf area of oil palm seedlings

Table 3. Total leaf area of oil palm seedlings $\left(\mathrm{cm}^{2}\right)$ in each treatment tested.

\begin{tabular}{lc}
\hline Treatment & Total leaf area $\left(\mathrm{cm}^{2}\right)$ \\
\hline $\mathrm{M}_{1}: 100 \%$ NPK & $173.18 \mathrm{~b}$ \\
$\mathrm{M}_{2}:$ OPEFB compost & $78.56 \mathrm{c}$ \\
$\mathrm{M}_{3}: 50 \%$ NPK + OPEFB compost & $185.04 \mathrm{ab}$ \\
$\mathrm{M}_{4}: 50 \%$ NPK + OPEFB + cellulolytic bacterial consortium & $196.90 \mathrm{a}$ \\
$\mathrm{M}_{5}:$ OPEFB + cellulolytic bacterial consortium & $79.91 \mathrm{c}$ \\
\hline
\end{tabular}

Note: The numbers in the column are followed by different lowercase letters significant effect according to the DMRT advanced test at the level of $5 \%$. 
Table 4. Increase in stem diameter of palm oil $(\mathrm{cm})$ in each treatment tested.

\begin{tabular}{lccc}
\hline \multicolumn{1}{c}{ Treatment } & $\begin{array}{c}\text { Stem } \\
\text { Diameters at } \\
\text { the beginning }\end{array}$ & $\begin{array}{c}\text { Stem } \\
\text { Diameters } \\
\text { at the end }\end{array}$ & $\begin{array}{c}\text { Increase in } \\
\text { Stem } \\
\text { Diameters }\end{array}$ \\
\hline $\mathrm{M}_{1}: 100 \% \mathrm{NPK}$ & 1.06 & 3.22 & $2.160 \mathrm{a}$ \\
$\mathrm{M}_{2}:$ OPEFB compost & 1.2 & 2.34 & $1.145 \mathrm{~b}$ \\
$\mathrm{M}_{3}: 50 \% \mathrm{NPK}+$ OPEFB compost & 0.8 & 3.24 & $2.200 \mathrm{a}$ \\
$\mathrm{M}_{4}: 50 \% \mathrm{NPK}+$ OPEFB + cellulolytic bacterial consortium & 1.05 & 3.1 & $2.050 \mathrm{a}$ \\
$\mathrm{M}_{5}:$ OPEFB + cellulolytic bacterial consortium & 1.25 & 2.4 & $1.152 \mathrm{~b}$ \\
\hline
\end{tabular}

showed that the treatment of NPK, OPEFB, and OPEFB compost gave a significant effect on the total leaf area. DMRT follow-up test results at the $5 \%$ level are presented in Table 3 .

Table 3 shows that the $M_{4}$ treatment resulted in the widest leaf area was not significantly different from $M_{3}$ treatment and was significantly different from other $\mathrm{M}_{3}$ treatments. This is suspected due to the provision of organic matter OPEFB which was added to the cellulolytic bacterial consortium which slowly decomposes and provides nutrients needed in plant growth. Also, the stocked organic matter of OPEFB can create good pore space, maintain soil moisture, and suppress weed growth. According to Widodo and Kusuma (2018), the addition of organic matter to the soil will increase water content due to increased soil pore so that the power to hold water increases. Besides, Hapsoh et al. (2019) stated that the provision of bacterial consortium applied through biofertilizers would support plant growth for the better. Three cellulolytic bacterial used in this study were Bacillus cereus. These bacteria are included in the PGPR bacterial group. This bacterium can produce phytohormone Indole Acetic Acid (IAA) (Gholami et al. 2009). This is thought to be one of the factors causing the area of palm oil leaves in the $M_{4}$ treatment to be better than the other treatments.

According to Ariyanti (2019), the leaf area describes the extent of the surface that plays a role in capturing the sun's rays needed for photosynthesis. Broader leaves tend to capture more sunlight so that they will contribute more to the photosynthates produced for the growth of other plant organs. The leaf area is strongly influenced by the N element. Lakitan (2007) added that nitrogen nutrients affect the formation of new cells, phosphorus plays a role in activating enzymes in the process of photosynthesis. Kiba et al. (2011) said that there is an interaction between phytohormones with nutrients $\mathrm{N}$ which ultimately affects the growth and development of plants.

\section{Increase in Stem Diameters of Oil Palm Seedlings}

The results of the analysis of variance showed that the treatment of NPK fertilizer, OPEFB compost, and OPEFB compost significantly affected the increase in stem diameter. The average increase in stem diameter after a DNMRT further test at $5 \%$ is presented in Table 4.

Table 4 shows that the $M_{3}$ treatment resulted in an increase in stem diameters was not significantly different from $M_{1}$ and $M_{4}$ treatments and was significantly different from $\mathrm{M}_{2}$ and $\mathrm{M}_{1}$ treatments. It was likely that the combination of inorganic and organic fertilizers given can equalize the growth of plants that are given nutrients through inorganic fertilizers. Yi et al. (2019) said that the use of organic fertilizers either alone or in combination with inorganic fertilizers will increase the nutrient content of the soil, improving the health of soils, and can reduce the use of inorganic fertilizers. Kurniawan (2012) reported that OPEFB compost in topsoil medium can improve soil structure, absorbency and save water better, and compost as an organic material can also provide nutrients for plants. The results of the study on the use of OPEFB compost increasing the stem diameter were also reported by Kusuma (2013) where the preparation of $20 \mathrm{Mg} \mathrm{ha}^{-1}$ OPEFB compost was able to increase the diameter of the stem at the nursery stage. Adnan (2015) reported that there was an interaction between $50 \%$ NPK fertilizer and $36 \mathrm{~g}$ per polybag organic fertilizer on the stem diameter of palm oil seedlings in the nursery.

The increase in the diameter of plant stems is strongly influenced by the elemental content of potassium and phosphor (Setyamidjaja 2006). According to Maryani (2018) who stated that the potassium element plays an important role in increasing the diameter of plant stems, especially in its role as a network that connects roots and leaves in the process of nutrient absorption. 
Table 5. Root to shoot ratio of oil palm seedlings (g) in each treatment tested.

\begin{tabular}{lc}
\hline \multicolumn{1}{c}{ Treatment } & Root to shoot ratio \\
\hline $\mathrm{M}_{1}: 100 \%$ NPK & $2.025 \mathrm{bc}$ \\
$\mathrm{M}_{2}:$ OPEFB compost & $1.757 \mathrm{c}$ \\
$\mathrm{M}_{3}: 50 \%$ NPK + OPEFB compost & $2.810 \mathrm{ab}$ \\
$\mathrm{M}_{4}: 50 \%$ NPK + OPEFB + cellulolytic bacterial consortium & $3.045 \mathrm{a}$ \\
$\mathrm{M}_{5}:$ OPEFB + Cellulolytic bacterial consortium & $1.480 \mathrm{c}$ \\
\hline
\end{tabular}

Note: The numbers in the column are followed by different lowercase letters significant effect according to the DMRT advanced test at the level of 5\%.

\section{Root to Shoot Ratio of Oil Palm Seedlings}

The results of the analysis of variance on the observation of root to shoot ratio of oil palm seedlings showed that that the addition of some NPK, OPEFB and OPEFB compost treatments significantly affected the root to shoot ratio. The average canopy ratio after further DNMRT tests at $5 \%$ is presented in Table 5 .

Table 5 shown that $\mathrm{M}_{4}$ treatment resulted in the best of root to shoot ratio was significantly different from other treatments and was not significantly different from $\mathrm{M}_{3}$ treatment. It is suspected that the structure of the planting with a combination of inorganic fertilizer with OPEFB compost or OPEFB + cellulolytic bacterial consortium better than only given inorganic or organic fertilizer. Kurniawan et al. (2014b) said that OPEFB compost in topsoil medium can improve soil structure, absorbability and store water better, and compost as an organic material can also provide nutrients for plants. This is supported by the results of the Situmorang study (2015), that the addition of OPEFB organic mulch resulted in an increase in total pore space, water content, $\mathrm{pH}, \mathrm{C}$-organic, total $\mathrm{N}$ and $\mathrm{K}$ which were significantly different from oil palm plantations. Fauzi and Puspita (2017) reported that the addition of OPEFB compost at a dose of 750 g plant $^{-1}$ and $P$ fertilizer 4.5 g plant $^{-1}$ increased root volume.

According to Yan and Gong (2010), using organic fertilizer also improves soil organic content with a larger yield trend along with a contribution to the carbon sequestration by favoring root development. Widodo and Kusuma (2018) added that the addition of compost can causes loose soil structure and increased soil pore which will later cause easy plant roots developing. The growth of root can be improved by improving soil structure by increasing organic matter in the soil, thereby increasing nutrient exchange capacity, providing better water retention in the soil, preventing soil acidity by supporting the soil, and reducing leaching of N and P lost through fixation (Sundram 2019).

\section{Dry Weight Biomassa of Oil Palm Seedlings}

The results of the analysis of variance on the observation of the total dry weight of biomass of oil palm seedlings showed that the addition of some NPK, OPEFB and OPEFB compost treatments significantly affected the dry weight of oil palm seedlings. Average seedling dry weight after DNMRT further testing at $5 \%$ is presented in Table 6 .

Table 6 shows the $M_{1}$ treatment produces the highest dry weight of plant but not significantly different with $M_{3}$ and $M_{4}$ treatments. Mishra and Dash (2014) said that fertilizers with high nutrient content are given with small amounts into the soil generally soluble and available to the plant immediately, which creates a direct, fast improvement in plants. However, the $\mathrm{M}_{3}$ and $\mathrm{M}_{4}$ treatments produced a relatively high dry weight of the plants such as the $M_{1}$ treatment. This shows

Table 6. Dry weight biomass of oil palm seedlings (g) in each treatment tested.

\begin{tabular}{lc}
\hline \multicolumn{1}{c}{ Treatment } & Dry weight biomass \\
\hline $\mathrm{M}_{1}: 100 \%$ NPK & $54.000 \mathrm{a}$ \\
$\mathrm{M}_{2}:$ OPEFB compost & $24.450 \mathrm{~b}$ \\
$\mathrm{M}_{3}: 50 \%$ NPK + OPEFB compost & $50.750 \mathrm{a}$ \\
$\mathrm{M}_{4}: 50 \% \mathrm{NPK}+$ OPEFB + cellulolytic bacterial consortium & $43.075 \mathrm{a}$ \\
$\mathrm{M}_{5}:$ OPEFB + cellulolytic bacterial consortium & $25.400 \mathrm{~b}$ \\
\hline
\end{tabular}

Note: The numbers in the column are followed by different lowercase letters significant effect according to the DMRT advanced test at the level of 5\%. 
that the combination of organic and inorganic fertilizers will also increase plant dry weight.

This is thought to be the case for both OPEFB and OPEFB compost given a cellulolytic bacterial consortium that contributes nutrients to plants even though they are available slowly but eventually can be absorbed by the roots. The availability of nutrients supports increasing plant dry weight. Nutrients from OPEFB compost help the metabolic processes of plants that trigger plant organ formation. It can be seen from the increase in height, a diameter of the stem, and some leaves and total leaf area in the seeds of oil palm plants. This is supported by the results of a study by Fauzi and Puspita (2017) reported that interaction between OPEFB compost and $\mathrm{P}$ fertilizer gave a good influence on all parameters, namely plant height, leaf number, stem diameter, root volume, seed dry weight, root to shoot ratio, leaf area, and dry weight of oil palm seedlings aged 7 months. Sijabat and Wawan (2017) added that the addition of $100 \mathrm{~g} /$ $10 \mathrm{~kg}$ OPEFB compost combination media with 10 $\mathrm{g} / 10 \mathrm{~kg}$ NPK fertilizer media was the best combination of treatments to increase plant height, leaf number, stem diameter, root volume, plant dry weight and ratio root crown of oil palm seedlings aged 3-6 months in Ultisol soil media.

All parameters generated by the treatments of $M_{2}$ and $M_{5}$ were much lower because the plants experience nutrient deficiencies so that a combination of inorganic fertilizers is needed to provide better nutrients. According to Widodo and Kusuma (2018), compost does not affect the vegetative growth of plants but it significantly influences changes in physical characteristics such as increasing soil pores and reducing the weight of soil contents. Therefore, to increase the growth of oil palm seedling and improve soil health by combining fertilizers (inorganic, organic, and microbial-based products) (Sundram 2019).

\section{CONCLUSIONS}

It can be concluded that firsly, giving a combination of $50 \% \mathrm{NPK}+\mathrm{OPEFB}$ compost gives the best effect on the parameters of increasing the height of oil palm seedlings, stem diameter, number of leaves and dry weight of seedlings, while the combination of $50 \%$ NPK + OPEFB + cellulolytic bacterial consortium provides the best leaf area and root to shoot ratio. Secondly, the organic fertilizer without inorganic fertilizer cannot provide plant growth on all parameters. Finally, application of OPEFB organic fertilizer given a cellulolytic bacterial consortium able to reduce the use of inorganic fertilizers by up to $50 \%$.

\section{ACKNOWLEDGMENTS}

Thank you to KEMENRISTEKDIKTI Republic of Indonesia for funding this research through the Competency Grant in 2018.

\section{REFERENCES}

Adnan SI, B Utoyo, A Kusumastuti. 2015. Pengaruh pupuk NPK dan pupuk organik terhadap pertumbuhan bibit kelapa sawit (Elaeis guineensis Jacq.) di main nursery. J Agro Industri Perkebunan 3: 69-81. doi: http://dx.doi.org/10.25181/aip.v3i2.20. (in Indonesian).

.Al-Khoiri. 2013. Perubahan sifat fisik berbagai jenis tanah di bawah tegakan kelapa sawit (Elaeis guineensis Jacq.) yang diaplikasi tandan kosong kelapa sawit (TKKS) di PT Salim Ivoma Pratama [Undergraduate Thesis]. Universitas Riau. Pekanbaru. (in Indonesian).

Anwar EK. 2009. Efektivitas cacing tanah Pheretima hupiensis, Edrellus sp. dan Lumbricus sp. dalam proses dekomposisi bahan organik. J Trop Soils 14: 149-158. (in Indonesian)

Ariyanti M, G Natali and C Suherman. 2017. The growth response of oil palm (Elaeis Guineensis Jacq.) seedling toward the application of organic fertilizer from palm fronds and NPK compound fertilizer. $J$ Agrikultura 28: 64-67.

Ariyanti M, Y Maxiselly, S Rosniawaty and RA Indrawan. 2019. The growth of immature oil palm with the application of oil palm midrib organic fertilizer and humic acid. J Oil Palm Res 27: 71-82.

Astralyna N. 2009. Pemanfaatan tandan kosong sawit (TKS) sebagai campuran media tumbuh dan pemberian mikoriza terhadap pertumbuhan bibit mindi (Melia azedarach L.). USU Press. Medan. (in Indonesian).

Bakeri SA, MST Maidin and MMM Masri. 2019. Soil bacterial biodiversity in development of secondary logged-over forest to oil palm plantation in mineral soil of Belaga, Sarawak. J Oil Palm Res 31: 394-411.

Fauzi A and F Puspita. 2017. Pemberian kompos TKKS dan pupuk $\mathrm{P}$ terhadap pertumbuhan bibit kelapa sawit (Elaeis Guineensis Jacq.) di pembibitan utama. JOM Faperta Universitas Riau 4 (2): 1-12.

Gholami A, S Shahsavani and S Nezarat. 2009. The effect of plant growth-promoting rhizobacteria (PGPR) on germination, seedling growth, and yield of maize. Intl Schol Sci Res Innov 3: 9-14.

Hapsoh, Wawan and IR Dini. 2016. Report on Research Results of Competency Grants. LPPM. Universitas Riau. Pekanbaru. (Unpublished).

Hapsoh, IR Dini, D Salbiah, Kusmiati. 2019. Growth and pepper yields (Capsicum annum L.) by giving formulation a biological fertilizer of cellulolytic bacteria based on organic liquid waste. IOP J Phys ConfSer 1351: 012097. doi:10.1088/1742-6596/1351/ $1 / 012097$. 
Hasibuan S, SI Saputra and Nurbaiti. 2014. Pengaruh Kompos Tandan Kosong Kelapa Sawit Dan Pupuk Npk Terhadap Pertumbuhan Bibit Kakao (Theobroma cacao L.). JOM Faperta Universitas Riau 1: 1-10. (in Indonesian).

Herviyanti, F Ahmad, R Sofyani, Darmawan, Gusnidar and A Saisi. 2012. . Pengaruh pemberian bahan humat dari ekstrak batubara muda (Subbituminus) dan pupuk P terhadap sifat kimia ultisol serta produksi tanaman jagung (Zea mays L.). J Solum 9: 15-24. doi: https:// doi.org/10.25077/js.9.1.15-24.2012.

Jannah N, F Abdul and Marhanuddin. 2012. Pengaruh macam dan dosis NPK majemuk terhadap pertumbuhan bibit kelapa sawit (Elaiei guineensis Jacq.). JMedia Sains 4: 48-54.

Jesus DJA. 2012. Utilization of empty bunches and bare ash of palm oil as an ameliorant for growth of palm oil seeds (Elaeis guineensis Jacq.) in main nurseries. [Thesis] Bogor Agricultural University. Bogor

Kaya E. 2014. Pertumbuhan pupuk organik dan pupukNPK terhadap $\mathrm{pH}$ dan K-tersedia tanah serta serapan-K, pertumbuhan, dan hasil padi sawah (Oryza sativa L.). Buana Sains 14: 113-122. doi: https://dx.doi.org/ 10.33366/bs.v14i2.353. (in Indonesian).

Kiba T, TKudo, M Kojima and H Sakakibara. 2011. Hormonal control of nitrogen acquisition: role of auxin, abscisic acid, and cytokinin. J Exp Bot 62: 1399-1408.

Kiswondo S. 2011. Penggunaan abu sekam dan pupuk ZA terhadap pertumbuhan dan hasil tanaman tomat (Lycopersium esculentum Mill.). Embryo 8 : 9-17. (in Indonesian).

Kurniawan D. 2012. Effect of medium composition of sand and compost on growth and development of palm oil seeds (Elaeis gueneensis Jacq.) in nurseries. Faculty of Agriculture, University of Riau. Pekanbaru.

Kurniawan NA, S Kumalaningsih and A Febrianto. 2014a. Pengaruh penambahan konsentrasi microbacter Alfaaf - 11 (MA - 11) dan penambahan urea terhadap kualitas pupuk kompos dari kombinasi kulit dan jerami nangka dengan kotoran kelinci. Fakultas Teknologi Pertanian Universitas Brawijaya. Malang. (in Indonesian).

Kurniawan R, RR Lahay, S Silitonga. and C Hanum. 2014b. Tanggap pertumbuhan dan produksi jagung manis pada pemberian mikroorganisme bermanfaat dan kompos tandan kosong kelapa sawit. J Online Agroekoteknologi 2: 1172-1181. (in Indonesian).

Kusuma H. 2013. Pemberian kompos tandan kosong kelapa sawit rotasi kedua dan ZPT alami di medium Subsoil Ultisol terhadap pertumbuhan bibit kelapa sawit (Elaeis guineensis Jacq) [Undergraduate Thesis]. Universitas Riau, Pekanbaru. (in Indonesian).

Lakitan B. 2007. Fundamentals of Plant Physiology. Raja Grafindo Persada. Jakarta.

Nengsih Y. 2015. Pemberian pupuk organik dan pupuk anorganik terhadap pertumbuhan bibit kelapa sawit (Elaeis guineensis Jacq.) di pembibitan utama. $J$ Ilmiah Universitas Batanghari Jambi 15: 107-112. doi: http://dx.doi.org/10.33087/jiubj.v15i4.132. (in Indonesian).
Pahan I. 2010. Panduan Lengkap Kelapa Sawit Manajemen Agribisnis Dari Hulu Hingga Hilir. Penebar Swadaya. Jakarta, 412 p. (in Indonesian).

Plantation Fund Management Agency. 2018. https:// www.bpdp.or.id/id/. Accessed $10^{\text {th }}$ October 2018.

Rosenani AB, R Rovica, PM Cheah and CT Lim. 2016. Growth performance and nutrient uptake of oil palm seedling in a prenursery stage as influenced by oil palm waste compost in growing media. Int J Agron Article ID 6930735: 1-8. doi: https://doi.org/10.1155/ 2016/6930735.

Sari VI, Sudradjat and Sugiyanta. 2015. The role of organic fertilizer in increasing the effectiveness of NPK fertilizers in oil palm seedlings in the main nursery. Indonesian J Agron 43: 153-159. doi: https://doi.org/ 10.24831/jai.v43i2.10422.

Sembiring JV, Nelvia and AE Yulia. 2015. Pertumbuhan bibit kelapa sawit (Elaeis guneensis Jacq.) di pembibitan utama pada medium subsoil ultisol yang diberi asam humat dan kompos tandan kosong kelapa sawit. J Agroteknologi 6: 25-32. doi: http:// dx.doi.org/10.24014/ja.v6i1.1373. (in Indonesian).

Setyamidjaja D. 2006. Palm oil. Kanisius. Yogyakarta. $127 \mathrm{p}$. (in Indonesian).

Sijabat RJ and Wawan. 2017. Growth of oil palm seedlings (Elaeis guineensis Jacq.) on ultisol media given various combinations of oil palm empty fruit bunch (compost) compost with NPK fertilizer. JOM Faperta Universitas Riau 4: 1-13.

Situmorang PC, Wawan and MA Khoiri. 2015. Effect of groundwater depth and organic mulch on the physical and chemical properties of peat soil in oil palm plantations (Elaeis guineensis Jacq.). JOM Faperta Universitas Riau 2: 15p.

Statisticsof Riau Province. 2018. Riau Province in Figures. BPS-Statisticsof Riau Province. Pekanbaru.

Sundram S, LPLAngel and SA Sirajuddin. 2019. Integrated balanced fertilizer management in soil health rejuvenation for a sustainable oil palm cultivation: a review. J Oil Palm Res 31: 348-363.

Sutedjo MM. 2008. Pupuk dan Cara Pemupukan. Rineka Cipta. Jakarta. (in Indonesian).

Widodo KH and Z Kusuma. 2018. Pengaruh kompos terhadap sifat fisik tanah dan pertumbuhan tanaman jaguung di Inceptisol. J Tanah dan Sumberdaya Lahan 5: 959-967. (in Indonesian).

Yan X and W Gong. 2010. The role of chemical and organic fertilizers on yield, yield variability, and carbon sequestration-resulted of a 19-year experiment. Plant Soil 331: 471-480

Yeboah E, P Ofori, GW Quansah, E Dugan, and SP Sohi. 2009. Improving soil productivity through biochar amendments to soils. Afr J Environ Sci Technol 3: 34-41. doi: https://doi.org/10.5897/AJEST08.156

Yi LG, SAA Wahid, P Tamilarasan and CS Siang. 2019. Enhancing Sustainable oil palm cultivation using compost. J Oil Palm Res 31: 412-421. doi: https:// doi.org/10.21894/jopr.2019.0037. 